\title{
Effects of combined HHP and heat treatment on viscosity attributes and microbiological condition of liquid egg yolk
}

\author{
ADRIENN TÓTH ${ }^{1 *}$, CSABA NÉMETH ${ }^{2}$, ILDIKÓ ZEKE ${ }^{1}$, \\ ANNAMÁRIA BARKÓI ${ }^{1}$, KARINA HIDAS ${ }^{1}$ and LÁSZLÓ FRIEDRICH ${ }^{1}$
}

${ }^{1}$ Department of Refrigeration and Livestock Product's Technology, Faculty of Food Science, Szent István University, Ménesi út 43-45, 1118 Budapest, Hungary

${ }^{2}$ Capriovus Ltd., Dunasor 073/72 hrsz., 2317 Szigetcsép, Hungary

\section{CONFERENCE FULL PAPER}

Received: January 31, 2020 • Accepted: September 24, 2020

Published online: October 30, 2020

(C) 2020 The Author(s)

\section{ABSTRACT}

Minimal processing technologies, like High Hydrostatic Pressure (HHP), heat treatments at low temperatures have an increasing role in food industry. Eggs are considered as functional foods, but for high retention of biological active compounds adequate minimal processing technologies are needed during preservation procedure. In our study, liquid egg yolk (LEY) was examined to meet consumer's expectations.

Combinations of pasteurization $\left(57-63{ }^{\circ} \mathrm{C}, 5-7 \mathrm{~min}\right)$ and HHP (350-400 $\mathrm{MPa}, 5 \mathrm{~min}$ ) were used to provide microbiological stability of LEY. After these treatments samples were examined for mesophyll aerobes and Enterobacteriaceae cell counts (using Nutrient agar an incubation of $30{ }^{\circ} \mathrm{C}, 48 \mathrm{~h}$ ) and viscosity attributes (Anton Paar MCR 92).

Our results show that microbiological stability is significantly influenced by the different parameters of heat treatments and HHP. Heat treatment effected at least 3 orders of magnitude decrease in cell count. Viscosity attributes point out that higher pressure of HHP have a stronger effect on viscosity than the temperature of pasteurization.

The results point out a great opportunity for industrial use of minimal processing technologies for LEY. Microbiological safety is strongly influenced by the order of treatments, but viscosity may be independent from the order of the treatments.

\footnotetext{
*Corresponding author. Email: Toth.Adrienn@szie.hu
} 


\section{KEYWORDS}

HHP, minimal processing, egg products, liquid egg yolk

\section{INTRODUCTION}

The poultry industry is one of the fastest growing animal industries globally. The world egg production reached $68.26 \mathrm{Mt}$ in 2013, with an increase of $94.6 \%$ from $35.07 \mathrm{Mt}$ in 1990 (Anonymous, n.d.). Eggs are one of the most nutrient dense foods (McNamara \& Thesmar, 2005). Hen's eggs have been reported to be a nutrient-dense food with high-quality protein, which is present in both the egg white and the yolk. Regarding micronutrient composition, one large egg (63-73 g) contains $186 \mathrm{mg}$ cholesterol, $126 \mathrm{mg}$ choline, $0.2 \mathrm{mg}$ riboflavin, $0.5 \mathrm{mg}$ vitamin $B_{12}, 24 \mathrm{mg}$ folate, $0.1 \mathrm{mg}$ vitamin $B_{6}$, $41 \mathrm{IU}$ vitamin $\mathrm{D}, 270 \mathrm{IU}$ vitamin $\mathrm{A}, 0.5 \mathrm{mg}$ vitamin E, $99 \mathrm{mg}$ phosphorus, and $0.9 \mathrm{mg}$ iron. These nutrients are distributed between the egg white and the yolk (McNamara, 2013; Benahmed et al., 2017; Banovic et al., 2018).

Egg yolk is well known as a natural oil-in-water emulsion. Because of its multifunctional properties egg yolk is extensively used in the food, medical, pharmaceutical, and cosmetics industries (Laca et al., 2015; Chalamaiah et al., 2017). Egg yolk is made of approximately 52\% dry matter, about $65 \%$ of which is fat, $31 \%$ proteins, and the remaining $4 \%$ carbohydrates, vitamins, and minerals (Guilmineau et al., 2005).

Emulsions are metastable systems that tend to destabilize through a number of mechanisms (e.g., creaming, coalescence, flocculation). In order to increase emulsion stability, which is a key factor for egg yolk's commercial applications, $\mathrm{pH}$ modification or heat treatment stabilization must be used (Bengoechea et al., 2010). Hen egg yolk is an ideal example of natural supramolecular assemblies of lipids and proteins with different organization levels. These assemblies are mainly due to interactions between proteins and phospholipids, and these interactions are essential in understanding and controlling the production of food made with yolk, and particularly emulsions (Anton, 2013).

Food industry prefers to use treated egg products instead of shell eggs. Eggs removed from shell are categorized in several ways, but the most often used categories are liquids, powders, or boiled eggs (Alamprese, 2017; Pelletier, 2017). The use of egg products increases the efficiency of food production and decreases the amount of food waste, while more economic producing is achieved.

In egg product industry, the microbiological safety of liquid products is mainly guaranteed by pasteurization. The United States Department of Agriculture (USDA) requires that liquid whole egg (LWE) is at least heated at $60{ }^{\circ} \mathrm{C}$ for no less than $3.5 \mathrm{~min}$, but in the United Kingdom the recommendations are to pasteurize at least at $64{ }^{\circ} \mathrm{C}$ for $2.5 \mathrm{~min}$ (Rossi et al., 2010; Korver \& McMullen, 2017). In France, there is no statutory heat treatment; only microbiological results are determined by regulations. To achieve this, the classically used treatment is to pasteurize whole egg at from 65 to $68{ }^{\circ} \mathrm{C}$ for 2-5 min in order to ensure 5-6 decimal reductions of vegetative microorganisms and especially Salmonella and Listeria monocytogenes (Baron et al., 2010). Pasteurization temperatures used in the egg industry are limited by the sensitivity of egg proteins to heat treatment. Thus, pasteurization for 2-10 min from 60 to $68{ }^{\circ} \mathrm{C}$ modifies whole egg electrophoretic pattern by especially decreasing ovotransferrin, livetin, ovalbumin, 
apovitellenin, lysozyme, and/or ovomucin band intensity (Bartlett \& Hawke, 1995; Rossi et al., 2010; Lechevalier et al., 2017).

The new consumer expectations regarding sensorial attributes led the food industry to apply minimal processing technologies aiming at the preservation of bioactive compounds and extending the shelf-life of treated products (Barbosa-Cánovas et al., 2011). One of the most promising technologies is the high hydrostatic pressure (HHP). Nutritionally, it enhances the intake of dietary nutrients in human by converting the complex ones into smaller ones (McInerney et al., 2007). Applications of HHP in food industries includes reduction in spoilage of food, enhancing safety of foods, retaining freshness of food commodities, and improving the shelf life of food items without/with minimal use of preservatives (Considine et al., 2008). As compared to traditional food processing technologies, HHP has less adverse and detrimental effects on quality and nutritional characteristics of food items during processing or preservation. This novel food processing technology is mainly derived from material science as in this technique food is normally treated at $>100 \mathrm{MPa}$ (mega Pascal) pressure. This technique is extensively evaluated. During food processing, high pressure applied to food item is equal from all directions, conducted through items uniformly and quickly by the pressure transferring medium which is not dependent upon geometry (Oey et al., 2008; Khan et al., 2018).

The aim of our experiment was to evaluate the changes in microbiological safety and viscosity attributes of liquid egg yolk (LEY) treated with different HHP and heat treatment combinations.

\section{MATERIAL AND METHODS}

\section{Sample preparing}

Homogenized LEY was taken from the production line of Capriovus Ltd. (Szigetcsép, Hungary). Samples were transferred to Szent István University, Dep. of Refrigeration and Livestock Products Technologies under refrigerated conditions $\left(4-6{ }^{\circ} \mathrm{C}\right)$ directly after production. Samples $(9 \times 250 \mathrm{~mL}$ for investigation of techno functional properties and $9 \times 3 \times 50 \mathrm{~mL}$ for microbiological tests) were packaged in high border polyethylene plastic bags.

All samples were first pasteurized than HHP treated. Heat treatments were $57{ }^{\circ} \mathrm{C}, 10 \mathrm{~min}$ or $63{ }^{\circ} \mathrm{C}, 7 \mathrm{~min}$. After heat treatment samples were cooled to room temperature in melting ice. HHP treatments were carried out in a Resato FPU 100-2,000 HHP equipment at $20{ }^{\circ} \mathrm{C}$. The range of pressure build up was $100 \mathrm{MPa} / \mathrm{min}$, and the unpressurization was immediate after treatment. HHP treatment was carried out for $5 \mathrm{~min}$ on 350 or $400 \mathrm{MPa}$. Samples were cooled down to $4{ }^{\circ} \mathrm{C}$ before measuring viscosity and microbiological load. Table 1 summarizes the different treatment parameters and sample coding used in this work.

\section{Inspection of viscosity attributes}

Viscosity attributes were investigated with an Anton Paar MCR 92 viscosimeter. The sample temperature was $15^{\circ} \mathrm{C}$ and data were collected between 10 and 1,000 1/min share rate. The flow charts were analyzed by Herschel-Bulkley models using the formula: 
Table 1. Applied treatment parameters of LEY and sample coding

\begin{tabular}{lcccc}
\hline Sample & $\begin{array}{c}\text { Temperature of heat } \\
\text { treatment, }{ }^{\circ} \mathrm{C}\end{array}$ & $\begin{array}{c}\text { Time of heat } \\
\text { treatment, min }\end{array}$ & $\begin{array}{c}\text { Pressure of } \\
\text { HHP, MPa }\end{array}$ & $\begin{array}{c}\text { Holding time of } \\
\text { HHP, min }\end{array}$ \\
\hline 1 & 0 & 0 & 0 & 0 \\
2 & 0 & 0 & 350 & 5 \\
3 & 0 & 0 & 400 & 5 \\
4 & 57 & 10 & 0 & 0 \\
5 & 63 & 7 & 0 & 0 \\
6 & 57 & 7 & 350 & 5 \\
7 & 63 & 10 & 350 & 5 \\
8 & 57 & 7 & 400 & 5 \\
9 & 63 & 400 & 5 \\
\hline
\end{tabular}

$$
\tau=\tau_{0}+K \gamma^{n},
$$

The analyzed constants are collected in Table 2.

\section{Microbiological testing}

In microbiological testing samples (3 repetitions for every sample, $50-50 \mathrm{~mL}$ each) were taken in sterile conditions. The storage temperature before measurement was $-4{ }^{\circ} \mathrm{C}$. After treatments samples were examined in $24 \mathrm{~h}$ for mesophyll aerobes and Enterobacteriaceae cell counts (using nutrient agar and usual incubation of $30{ }^{\circ} \mathrm{C}$ for $48 \mathrm{~h}$ ).

\section{RESULTS AND DISCUSSION}

The evaluation of viscosity attributes is summarized in Table 3. The combined treatments show a difference in viscosity attributes. However, results of the fitted models are not for every sample well acceptable $\left(R^{2}<0.95\right)$. Similar results are published in case of liquid egg white and liquid whole egg (Wardy et al., 2014). In case of fruits, e.g., mango, HHP and heat treatment modified viscosity as well (Liu et al., 2014). According to the literature, changes are significant almost in every food product, independent from its plant or animal origin (Bengoechea et al., 2010).

Table 2. The nomenclature of Herschel-Bulkley model parameters

\begin{tabular}{lc}
\hline Constant & Nomenclature \\
\hline$\gamma$ & Shear rate $(1 / \mathrm{s})$ \\
$\tau$ & Yield stress (Pa) \\
$\tau_{0}$ & Yield stress (Pa) \\
$K$ & Consistency factor (Pas) \\
$N$ & Flow index, a power law exponent (-) \\
$R^{2}$ & Goodness of fitted model (-) \\
\hline
\end{tabular}

Source: (Elgaddafi et al., 2016). 
Table 3. Calculated constants of Herschel-Bulkley models of treated LEY samples

\begin{tabular}{lrrrrrrrrc}
\hline Sample constant & \multicolumn{1}{c}{1} & \multicolumn{1}{c}{2} & \multicolumn{1}{c}{3} & \multicolumn{1}{c}{4} & \multicolumn{1}{c}{5} & \multicolumn{1}{c}{6} & 7 & \multicolumn{1}{c}{8} & 9 \\
\hline$\tau_{0}$ & -0.72 & -1.09 & -3.4 & -5.64 & -1.06 & -4.35 & 3.64 & 0.26 & -1.22 \\
$K$ & 0.92 & 1.35 & 13.24 & 23.17 & 16.41 & 26.46 & 47.27 & 41 & 31.6 \\
$N$ & 0.85 & 0.81 & 0.53 & 0.46 & 0.5 & 0.44 & 0.39 & 0.4 & 0.39 \\
$R^{2}$ & 0.99 & 0.96 & 0.94 & 0.93 & 0.94 & 0.95 & 0.96 & 0.97 & 0.96 \\
\hline
\end{tabular}

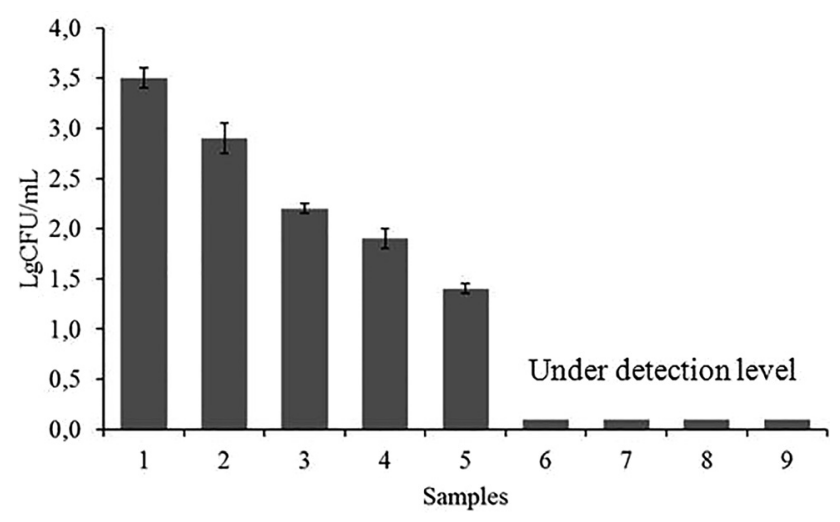

Fig. 1. Mesophyll aerobe cell count of HHP and heat treated LEY

Microbiological spoilage of LEY was sufficiently decreased by combined HHP and heat treatment. Enterobacteraceae were not detected in the examined samples. Fig. 1 shows the mesophyll aerobe cell count.

Our results show that first heat treated, then HHP treated LEY samples had a significant lower microbial spoilage. In contrast, single HHP (sample 2, 3), or single heat treatment (sample $4,5)$ has a lower effect on microbiota. Other studies point out that minimal processing treatments are sufficient for microbiological safety of egg yolk (Badr, 2006).

The HHP treatment of egg white (Toth et al., 2017) has a high influence on microbiota and rheological properties. Some studies point out that HHP has a higher impact on viscosity of liquid egg products, than heat treatment (Németh et al., 2012).

\section{CONCLUSIONS}

Our results show that HHP and heat treatment influence significantly the viscosity attributes of LEY. The parameters of both treatments have high impact on viscosity of LEY, which has an industrial relevance as well. For reducing rheological changes higher temperature of heat treatment and lower pressure of HHP are proposed.

Microbiological tests highlighted that the order of applied HHP and heat treatment have an important role in microbiological safety of LEY. In aspect of food safety the best choice is using heat treatment at first and then HHP. 


\section{ACKNOWLEDGMENTS}

Our research is supported by EFOP-3.6.3.-VEKOP-16-2017-00005 and by "Egg white based dairy product analogs with probiotic effects for allergic people and development of low-fat and carbohydrate products for people on a protein-dense diet VÁLLALATI KFI_16-1-2017-0551". We are very thankful for that. We are very grateful for the help of the colleges of Capriovus Ltd. and Dep. of Refrigeration and Livestock Products Technologies.

\section{REFERENCES}

Alamprese, C. (2017). Chapter 24 - the use of egg and egg products in pasta production. In: Hester, P.Y. (Ed.), Egg innovations and strategies for improvements. Academic Press, San Diego. pp. 251-259, https://doi.org/10.1016/B978-0-12-800879-9.00024-X.

Anonymous (undated). World agriculture: towards 2015/2030 - an FAO perspective.Retrieved June 9, 2017, from http://www.fao.org/docrep/005/y4252e/y4252e07.htm.

Anton, M. (2013). Egg yolk: structures, functionalities and processes. Journal of the Science of Food and Agriculture, 93(12): 2871-2880, https://doi.org/10.1002/jsfa.6247.

Badr, H.M. (2006). Effect of gamma radiation and cold storage on chemical and organoleptic properties and microbiological status of liquid egg white and yolk. Food Chemistry, 97(2): 285-293, https://doi. org/10.1016/j.foodchem.2005.05.004.

Banovic, M., Arvola, A., Pennanen, K., Duta, D.E., Brückner-Gühmann, M., Lähteenmäki, L., and Grunert, K.G. (2018). Foods with increased protein content: a qualitative study on European consumer preferences and perceptions. Appetite, 125: 233-243, https://doi.org/10.1016/j.appet.2018.01.034.

Barbosa-cánovas, G.V., Ghani, A., Juliano, P., and Knoerzer, K. (2011). Introduction to innovative food processing technologies: background, advantages, issues, and need for multiphysics modeling. Innovative Food Processing Technologies: Advances in Multiphysics Simulation, 3-21, https://doi.org/10. 1002/9780470959435.ch1.

Baron, F., Jan, S., and Jeantet, R. (2010). Qualité microbiologique des ovoproduits. Sciences et technologie de l'œuf: de l'œuf aux ovoproduits, 321-349.

Bartlett, F.M. and Hawke, A.E. (1995). Heat resistance of listeria monocytogenes scott A and HAL 957E1 in various liquid egg products. Journal of Food Protection, 58(11): 1211-1214, https://doi.org/10.4315/ 0362-028X-58.11.1211.

Benahmed, F., Wang, H., Beaubrun, J.J.-G., Gopinath, G.R., Cheng, C.-M., Hanes, D.E., Hammack, T.S., Rasmussen, M., and Davidson, M.K. (2017). Detection of salmonella enterica subsp. Enterica serovar cubana from naturally contaminated chick feed. Journal of Food Protection, 80(11): 1815-1820, https:// doi.org/10.4315/0362-028X.JFP-16-344.

Bengoechea, C., Romero, A., Aguilar, J.M., Cordobés, F., and Guerrero, A. (2010). Temperature and pH as factors influencing droplet size distribution and linear viscoelasticity of $\mathrm{O} / \mathrm{W}$ emulsions stabilised by soy and gluten proteins. Food Hydrocolloids, 24(8): 783-791, https://doi.org/10.1016/j.foodhyd.2010.04. 005.

Chalamaiah, M., Esparza, Y., Temelli, F., and Wu, J. (2017). Physicochemical and functional properties of livetins fraction from hen egg yolk. Food Bioscience, 18: 38-45, https://doi.org/10.1016/j.fbio.2017.04. 002. 
Considine, K.M., Kelly, A.L., Fitzgerald, G.F., Hill, C., and Sleator, R.D. (2008). High-pressure processing Effects on microbial food safety and food quality. - FEMS Microbiology Letters, 281(1): 1-9, https://doi. org/10.1111/j.1574-6968.2008.01084.x.

Elgaddafi, R., Ahmed, R., and Growcock, F. (2016). Settling behavior of particles in fiber-containing Herschel Bulkley fluid. Powder Technology, 301: 782-793, https://doi.org/10.1016/j.powtec.2016.07.006.

Guilmineau, F., Krause, I., and Kulozik, U. (2005). Efficient analysis of egg yolk proteins and their thermal sensitivity using sodium dodecyl sulfate polyacrylamide gel electrophoresis under reducing and nonreducing conditions. Journal of Agricultural and Food Chemistry, 53(24): 9329-9336, https://doi. org/10.1021/jf050475f.

Khan, M.K., Ahmad, K., Hassan, S., Imran, M., Ahmad, N., and Xu, C. (2018). Effect of novel technologies on polyphenols during food processing. Innovative Food Science \& Emerging Technologies, 45: 361-381, https://doi.org/10.1016/j.ifset.2017.12.006.

Korver, D. and McMullen, L. (2017). Chapter 4 - egg production systems and salmonella in Canada. In: Producing safe eggs, Academic Press, San Diego, pp. 59-69, https://doi.org/10.1016/B978-0-12-8025826.00004-5.

Laca, A., Paredes, B., Rendueles, M., and Díaz, M. (2015). Egg yolk plasma: separation, characteristics and future prospects. LWT - Food Science and Technology, 62(1, Part 1): 7-10, https://doi.org/10.1016/j.lwt. 2015.01.048.

Lechevalier, V., Guérin-Dubiard, C., Anton, M., Beaumal, V., David Briand, E., Gillard, A., Le Gouar, Y., Musikaphun, N., Tanguy, G., Pasco, M., Dupont, D., and Nau, F. (2017). Pasteurisation of liquid whole egg: optimal heat treatments in relation to its functional, nutritional and allergenic properties. Journal of Food Engineering, 195: 137-149, https://doi.org/10.1016/j.jfoodeng.2016.10.007.

Liu, F., Li, R., Wang, Y., Bi, X., and Liao, X. (2014). Effects of high hydrostatic pressure and high-temperature short-time on mango nectars: changes in microorganisms, acid invertase, 5-hydroxymethylfurfural, sugars, viscosity, and cloud. Innovative Food Science \& Emerging Technologies, 22: 2230, https://doi.org/10.1016/j.ifset.2013.11.014.

McInerney, J.K., Seccafien, C.A., Stewart, C.M. \& Bird, A.R. (2007): Effects of high pressure processing on antioxidant activity, and total carotenoid content and availability, in vegetables. Innovative Food Science and Emerging Technologies, 8(4): 543-548, https://doi.org/10.1016/j.ifset.2007.04.005.

McNamara, D.J. (2013). Eggs. In: Caballero, B. (ed.), Encyclopedia of human nutrition, 3rd ed. Academic Press, Waltham, pp. 132-138, https://doi.org/10.1016/B978-0-12-375083-9.00086-6.

McNamara, D.J. and Thesmar, H.S. (2005). Eggs. In: Caballero, B. (ed.), Encyclopedia of human nutrition, 2nd ed. Elsevier, Oxford, pp. 86-92, https://doi.org/10.1016/B0-12-226694-3/00098-3.

Németh, C., Dalmadi, I., Mráz, B., Friedrich, L., Zeke, I., Juhász, R., Suhajda, A., and Balla, C. (2012). Effect of high pressure treatment on liquid whole egg. High Pressure Research, 32(2): 330-336, https://doi.org/ 10.1080/08957959.2012.687050.

Oey, I., Lille, M., Van, L., and Hendrickx, M. (2008). Effect of high-pressure processing on colour, texture and flavour of fruit- and vegetable-based food products: a review. Trends in Food Science and Technology, 19(6): 320-328, https://doi.org/10.1016/j.tifs.2008.04.001.

Pelletier, N. (2017). Life cycle assessment of Canadian egg products, with differentiation by hen housing system type. Journal of Cleaner Production, 152: 167-180, https://doi.org/10.1016/j.jclepro.2017.03.050.

Rossi, M., Casiraghi, E., Primavesi, L., Pompei, C., and Hidalgo, A. (2010). Functional properties of pasteurised liquid whole egg products as affected by the hygienic quality of the raw eggs. LWT - Food Science and Technology, 43(3): 436-441, https://doi.org/10.1016/j.lwt.2009.09.008. 
Toth, A., Nemeth, C., Horváth, F., Zeke, I., and Friedrich, L. (2017). Impact of HHP on microbiota and rheological properties of liquid egg white, a kinetic study. Journal of Biotechnology, 256(Supplement): S93, https://doi.org/10.1016/j.jbiotec.2017.06.1119.

Wardy, W., Pujols Martínez, K.D., Xu, Z., No, H.K., and Prinyawiwatkul, W. (2014). Viscosity changes of chitosan solution affect physico-functional properties and consumer perception of coated eggs during storage. LWT - Food Science and Technology, 55(1): 67-73, https://doi.org/10.1016/j.lwt.2013.07.013.

Open Access. This is an open-access article distributed under the terms of the Creative Commons Attribution 4.0 International License (https://creativecommons.org/licenses/by/4.0/), which permits unrestricted use, distribution, and reproduction in any medium, provided the original author and source are credited, a link to the CC License is provided, and changes - if any - are indicated. (SID_1) 